\title{
Trump's Foreign Policy and International Trade Law
}

\author{
Política exterior y derecho comercial \\ internacional de Trump
}

\section{Politique étrangère et droit commercial international de Trump}

\begin{abstract}
Virdzhiniya Petrova Georgieva*
Sumario: I. Introduction. II. Free trade in International Law vs. neoprotectionism in Trump's Foreign Policy. III. Multilateralism in International Trade Law vs. bilateralism in Trump's Foreign Policy. IV. Conclusion. V. Bibliography.
\end{abstract}

* Investigadora en el Instituto de Investigaciones Jurídicas de la UNAM.

Artículo recibido el 3 de diciembre de 2018 Aprobado para publicación el 3 de octubre de 2019 
ABSTRACT: Donald Trump has based his Foreign Policy in the area of international trade on two main objectives. The first one seeks to promote "fair trade" in order to bring down trade deficits, restore reciprocity and balance in the trade relations of the United States with its trading partners and defend American commercial interests against and/or beyond other countries interests. On the second place, Trump's Foreign Policy intends to stop the de-location of productive activities from the United States and create new jobs to foster a strong and growing domestic economy. The concrete fulfilment of these objectives have shaken deeply the most central foundations of International Trade Law: a normative system build after the Second World War to give legal basis and regulate the economic relations between states in the new international liberal order. In the first place, Trump's Foreign Policy's neo-protectionism represents a frontal attack on free trade, as a dominant paradigm of International Trade Law. In the second place, the avowed bilateralism of this Policy is the exact opposite of the multilateralism, promoted by the norms and institutions of International Trade Law. Both neo-protectionism and bilateralism manifest a broader crisis of States' cooperation in the Post-World War II international liberal order.

Key words: United States' Foreign Policy, Neo-Protectionism, Bilateralism, International Trade Law.

RESUMEN: Donald Trump ha orientado su política exterior hacia dos objetivos económicos principales en materia de comercio exterior. El primero consiste en luchar por un fair trade que reequilibre la relación comercial de Estados Unidos con sus socios comerciales, a través de una lógica que privilegie a los intereses estadounidenses por encima de la búsqueda de intereses comunes. En virtud del segundo objetivo se busca frenar la des-localización de actividades productivas de Estados Unidos para impulsar la creación de nuevos empleos y estimular el crecimiento de la economía interna. Estos dos objetivos de la política exterior de Trump han sacudido profundamente los pilares más fundamentales del derecho del comercio internacional: un conjunto normativo, construido después de la Segunda Guerra Mundial para dar sustento jurídico a las relaciones económicas del nuevo orden internacional liberal. En primer lugar, el neoproteccionismo de la política exterior de Trump constituye una contestación frontal del libre comercio como paradigma dominante del derecho del comercio internacional. En segundo lugar, el confirmado bilateralismo de dicha política es el exacto opuesto del multilateralismo, promovido por las normas e instituciones de la regulación jurídica del comercio internacional. Tanto el neoproteccionismo como el bilateralismo manifiestan la existencia de una crisis más profunda de la cooperación entre Estados en el orden internacional liberal de la posguerra.

Palabras clave: política exterior de Estados Unidos, neo-proteccionismo, bilateralismo, derecho del comercio internacional. 


\section{INTRODUCTION}

Since his arrival at the White House, Donald Trump has favored a more active intervention of his Government in the volume and level of the United States' trade exchanges with the rest of the world. In many of his public statements, Trump blamed his trade partners of "taking advantage" of his country by "huge trade deficits", depredatory and unfair trade practices. The American Union's "horrible deals" with states that "aren't paying their bills" would have transformed it, on its detriment, in the "world's major consumer".

Trump has criticized, in the first place, the negative effects of these deals on the American economy and, especially, on the social and material wellbeing of its people. His political discourse on this point is matching with the profile of his major voters: white men without studies from the "Rust Belt" region: the industrial "heart" of the United States, composed by the States of Pennsylvania, Michigan, Wisconsin, Ohio and Minnesota. The de-location of many fabrics, which gave them, jobs for generations and their installation in developing countries, abundant in low-wage workers have been one of the principal subjects of Trump's presidential campaign. ${ }^{1}$ Since then, Trump promised to workers assembled in Indianapolis that "companies are not going to leave the United States anymore without consequences." After the elections, in his inauguration speech, he mentioned "the forgotten men and women of our country" and reassured them that they "will be forgotten no longer".

Using the neo-protectionist, mercantilist and nationalist slogans "America First" and "Make America Great Again", Trump has based his Foreign Policy in the area of international trade on two main objectives. The first one seeks to promote "fair trade" in order to bring down trade deficits, restore reciprocity and balance in the trade relations of the United States with its trading partners and defend American commercial interests against and/or beyond other countries interests ("America First"). On the second place, Trump's

1 Conesa Elsa, “Trump et les oubliés de la Rust Belt”, Les Echos, 17 Mai 2017, à 18h27, avalaible at: https://www.lesechos.fr/17/05/2017/lesechos.fr/0212101931369_trump-et-lesoublies-de-la-rust-belt.htm. 
Foreign Policy intends to stop the de-location of productive activities from the United States and create new jobs to foster a strong and growing domestic economy ("Make America Great Again"). ${ }^{2}$

The concrete fulfilment of these objectives has shaken deeply the most central foundations of International Trade Law: a normative system build after the Second World War to give legal basis and regulate the economic relations between states in the new international liberal order. International Trade Law was to bring legal security and predictability to international trade exchanges and the United States was his original architect and his "best student". Nowadays, we are facing a dramatic scenario in which the "creator" is attacking his own "creature".

This essay will study the consequences of Trump's Foreign Policy on the norms and institutions of International Trade Law and will try to demonstrate that it creates serious risks for the effective function of this specialized branch of International Law. In the first place, Trump's Foreign Policy's neo-protectionism represents a frontal attack on free trade, as a dominant paradigm of International Trade Law. In the second place, the bilateralism of this Policy is the exact opposite of the multilateralism, promoted by the norms and institutions of International Trade Law.

\section{FREE TRADE IN INTERNATIONAL LAW VS NEO-PROTECTIONISM IN TRUMP'S FOREIGN POLICY}

Free trade has been the economic foundation of the legal norms and institutions of International Trade Law since the end of the Second World War. The international trade theory demonstrated scientifically that protectionism is not an optimal international trade policy, as tariffs, export subsidies and im-

2 In his official Trade Policy Agenda for 2017, Trump's government explains, "The overarching purpose of our trade policy — the guiding principle behind all of our actions in this key area - will be to expand trade in a way that is freer and fairer for all Americans. Every action we take with respect to trade will be designed to increase our economic growth, promote job creation in the United States, promote reciprocity with our trading partners, strengthen our manufacturing base and our ability to defend ourselves, and expand our agricultural and services industry exports”, USTR, Trade Policy Agenda and 2016 Annual Report, Washington, Office of the United States Trade Representative, 2017, p. 1. 
port quotes on trade in goods cause market distortions and negatively affect production and consumption. There was a consensus to consider that the suppression of barriers to free trade guarantee a more efficient resource allocation, better possibilities for innovation (learning-by-doing) and research and development (R\&D). Free trade and global integration of markets was supposed to achieve, per se, a growth of the productivity and competitiveness of the export sectors of national economies. Consequently, the general level of productivity of domestic economies would grow and countries could reach a major economic development and a better social wellbeing and quality of life for their citizens.

The beliefs in the predictions of the conventional trade theory justified the adoption, on the international scale, of rules, specifically designed to give legal support to the process of international commercial liberalization. Since the Second World War, states members of the international community began to conclude international trade agreements, in order to liberalize trade in goods and services, remove trade barriers and provide market access, based on reciprocity and effectiveness. The fulminant proliferation of these agreements, at the regional, inter-regional, intra-regional and universal level, has created the image of a "spaghetti bowl", to use the famous expression of American Economist Jagdish Bhagwati. ${ }^{3}$ In fact, if in1995, there were no more than 100 free trade agreements, at present; WTO has registered 320 international commercial treaties, concluded between its member states. ${ }^{4}$ Every country has now signed at least one free trade agreement with the rest of the world. International trade agreements classically cover commercial liberalization of trade in goods and services, through the suppression of tariff and no tariff barriers to trade, but there are "last generation" trade agreements that also include legal regulations on "trade related measures" (trade and environment, trade and small and medium sized enterprises, trade and investment, electronic trade, trade and competition, etcetera). The sophistication of free trade promotion by international trea-

3 Bhagwati, Jagdish, y Panagariya, Arvind, “The Theory of Preferential Trade Agreements: Historical Evolution and Current Trends", The American Economic Review, vol. 86, 1996, pp. 82-87; Baldwin, Richard, Multilateralizing Regionalism. Challenges for the Global Trading System, Cambridge, World Trade Organization, 2009.

4 “Acuerdos comerciales regionales y arreglos comerciales preferenciales" Organización Mundial del Comercio, 2019, avalaible in: https://www.wto.org/spanish/tratop_s/region_s/rta_ pta_s.htm. 
Esta revista forma parte del acervo de la Biblioteca Jurídica Virtual del Instituto de Investigaciones Jurídicas de la UNAM

ties can now represent an extensive volume of disposals, which oscillates between 500 and 1500 pages for each agreement.

Free trade and its corollary- international investment- also supported the creation of many international interstate organizations, owing international legal personality and competent to regulate many aspects of the international economic activities. The International Monetary Fund, the World Bank, the International Center for Settlement of Investment Disputes, the large number of regional organizations for economic integration (for example, the European Union, the African Union, the Caribbean Community, the Union of South American Nations or the Eurasian Economic Community) as well as the World Trade Organization (WTO), "institutionalized" the international interstate cooperation on trade matters. The missions granted to these organizations by their member states refer to different aspects of international trade regulation. One of the two Bretton Woods "twins" institutions- the International Monetary Fund- received competences to control the stability of the exchange rates in the international monetary and financial relations, as the operations in this field are critical for the achievement of free trade objectives. Additionally, through the "Washington Consensus", both the International Monetary Fund and the World Bank were able to prepare and/or impose the structural reforms needed to adapt their member states domestic economies to the requirements of the trade liberalization. The International Center for Settlement of Investment Disputes was to grant legal security and protect the interests of investors (natural or legal persons) against some political risks in the "host state". The organizations for regional economic integration were to guarantee and expand free trade between its members, on the regional level, and WTO was to secure states free trade commitments on the multilateral or universal scale.

The free trade paradigm promoted the development of new mechanism as well of international dispute settlement. The States granted the responsibility to interpret and apply International Trade Law's rules to many judicial or quasi-judicial bodies with regional and universal jurisdiction. The Dispute Settlement Body of the World Trade Organization, the Tribunal of Justice of the European Union, the Caribbean Court of Justice, the Court of Justice of the Andean Community or the development of international 
commercial arbitration are some few examples of the ongoing process of "judicialization" of International Trade Law. ${ }^{5}$

This body of legal rules, institutions, dispute settlement mechanisms and their free trade paradigm organized the core of economic relations between states during the second half of the $20^{\text {th }}$ Century. However, in the beginning of the $21^{\text {st }}$ Century, the liberal foundation of International Trade Law seems to suffer a deep crisis. The 2008 economic and financial crisis and the fall-down of the sky-high home prices in the United States marked the "beginning of the end" of free trade as states exclusive commercial policy. In this regard, Trump's Foreign Policy is not a major cause, but a simple consequence of the exhaustion of commercial liberalization as a paradigm of International Trade Law. Trump is just a new and strong voice of many old problems of free trade in International Law.

The first obvious failure of commercial liberalization in International Trade Law has to deal with the elimination of trade barriers and the free access to domestic markets. In fact, the rules and principles of International Trade Law have focused on the elimination of both tariff and nontariff barriers. However, the only real success of International Trade Law has been the suppression of tariff barriers to trade. The global trade is now "duty free". Nevertheless, so far, International Trade Law has been unable to reach an optimal regulation and/or elimination of no-tariff barriers and their persistent proliferation is the major cause of trade disruptions and obstructions in many domestic markets. States still use thefts of trade secrets, sanitary and phytosanitary measures, technical barriers (especially in trade in services) and currency practices (such as depredatory devaluations) as trade restriction tactics. Countries have increased their level of "creativity" in the no-tariff barriers field and have affected unfairly the competitiveness of many export sectors in developing and developed countries. WTO's and other bilateral and plurilateral free trade agreements include rules on notariff trade barriers but their effective implementation in domestic policies has faced many political obstacles and protectionist "instincts" on behalf of States' governments.

Petrova Georgieva, Virdzhiniya, "La «judicialización»: una nueva característica del orden jurídico internacional”, Anuario Mexicano de Derecho Internacional, vol. XV, January-December 2015. 
On the second place, the positive effects of "economic liberalism through International Law" on trade growth are not at any doubt. Trade development as result of the integration of labor, capital, goods and services markets (by legal means) has been exponential since 1950. However, the positive effects of free trade in International Law on general economic development of the countries and on the social well-being of their nations are less obvious. Recent studies show that trade liberalization has not operated under the logic "win-win" and has created many "losers", not only between States in their trade exchange relations, but also between their own citizens. Indeed, free trade has caused harms to the non- qualified workers of the developed countries, exposing them to the "unfair" competition of the developing economies and their abundance of cheap labor. On the other hand, the workers in the developing states suffer "labor exploitation" and miserable salaries, which are the only way to preserve the competitiveness of their national exports. ${ }^{6}$ Finally, the workers in the agriculture- in many occasions, the most important sector of the domestic economies of developing countries, have been unable to compete with the export subsidies programs of the developed states. The de-location of productive activities and the inequality of the internal and international distribution of the benefits and economic rents, generated by free trade, has questioned its ability to drive national economies to further development. In other words, trade liberalization has not been an engine of growth for all. ${ }^{7}$

Beside these failures, all the Governments of the United States (democrats and republicans) have defended and promoted American leadership in international free trade since the end of the Second World War. Partly because trade liberalization was the best strategy of American multinational companies to get market access all around the world, and because free trade was seen by American Governments as a tool to maintain international peace and security through economic development.

However, the vision of multinational companies and the United States governments soon stood away from the opinion of large number of American citizens, who felt disappointed by free trade promises and harmed by its "perverse" effects. How can you convince a worker from the "Rust

6 Siroen, Jean-Marc, "L'OMC: une institution en crise", Alternatives Économiques, no. 240, 2008, p. 249.

7 Idem. 
Belt" who wins 25 dollars per hour that he must compete with a Mexican worker who wins 7 dollars per day? How do you make him sure that free trade is good, if it has made him lose his job? ${ }^{8}$ The lack of valid responses to these rhetorical questions brought to the Presidency of the United States a populist politician like Trump.

Trump's Foreign Policy takes account of the demands of the non- qualified American workers and contains severe critics to free trade promotion in International Trade Law. For Trump's Administration there are two principal present challenges to the promotion of commercial liberalization by the rules and institutions of International Trade Law. The first one must deal with countries that are not pursuing free trade principles in their domestic policies. In fact, one of Trump's Foreign Trade Policy's objective is "to use leverage to open trade markets", because "the WTO rules, and those of some bilateral and plurilateral trade agreements, are often written with the implicit understanding that countries implementing those rules are pursuing free-market principles". The second major concern of the Trump Administration about the promotion of free trade by International Law is the lack of transparence of many countries' domestic regulations and the use of opaque legal rules as a de facto no-tariff trade barrier. ${ }^{9}$

As response to free trade failures in International Law, Trump's Foreign Policy offers a "more aggressive approach", based on a neo-protectionism in some strategic sectors of the United States' economy. ${ }^{10}$ This neo-protectionism seeks to "encourage other countries to give U.S. producers fair

8 Trump et les oublié de la Rust Belt, op.cit.

9 In Trump's opinion, "the second challenge is that WTO rules, and those of bilateral and plurilateral trade agreements, are often written with the implicit understanding that countries implementing those rules have functional legal and regulatory systems that are transparent. In practice, transparent systems are critical to the functioning of trade rules because transparency enables stakeholders and governments to understand the rules of the road and prepare effective diplomatic or legal challenges to those rules when they are not in conformity with international obligations. Once again, the world in which we find ourselves is one in which there are a number of important players whose legal and regulatory systems are not sufficiently transparent. These countries make it difficult for the global trading system to hold them accountable. The inability of the system to hold those countries accountable in turn leads to a loss of confidence in the system", USTR, Trade Policy Agenda and 2016 Annual Report..., cit., p. 5.

10 Idem. 
and reciprocal access to their markets" 11 and relies on the use of the most classical tool of this international trade policy: the tariffs.

In this sense, since the beginning of 2018, Trump imposed tariffs for 25\% on the import of steel and aluminum to the United States. It's not a big surprise that he chooses precisely these two sectors to impose barriers on free trade. The United States was, during the $20^{\text {th }}$ Century, the major producer of steel and aluminum and its Siderurgy- a symbol of American economic power. Both metals have strategic value for domestic economies as they serve for the fabrication of many products and weapons and Trump's decision $^{12}$ to protect American producers by the imposition of tariffs in trade, thus, obeys to national security reasons. ${ }^{13}$ Trump's neo-protectionist Foreign Policy would use tariffs to create trade barriers for many more types of goods and Mexico's Secretary of Economy, Ildefonso Guajardo, has even suggested that the Trump Administration means to impose tariffs for $30 \%$ on the import of cars and auto parts.

Trump's indiscriminate use of tariffs have led the entire world in a global "trade war". ${ }^{14}$ In effect, all the states affected by those measures replied to Trump's neo-protectionist Foreign Policy by taking trade countermeasures and imposing additional duties on a number of imports from the United States. In the beginning of June 2018, Mexico and Canada suspended the tariff preferential treatment to many products of the United States. China did the same and notified to the World Trade Organization the imposition of additional duties of 15 and 25\% to imports from the United States (especially on agricultural products). In June 2018, the European Union's authorities expressed that the United States left them no other choice "but to proceed... with the imposition of additional duties on a number of imports from the US" in order to "defend the Union's interests, in full compliance

11 Idem.

12 "Acier et aluminium: pourquoi de nouveaux droits de douane au nom de la sécurité nationale”, France 24, Publié le 09/03/2018 - 17:47 Modifié le : 09/03/2018 - 20:14, available at: https://www.france24.com/fr/20180309-acier-aluminium-douane-protectionnisme-securite-nationale-trump-omc-regle.

13 The tariffs on aluminum and Steel imports applied to every country, except Mexico and Canada. The exemption of both governments was conditioned on the re-negotiation of NAFTA and the tariffs were finally imposed to them since the end of May 2018.

14 "Trade wars, Trump tariffs and protectionism explained”, BBC News, 10 May 2019, avalaible in: https: / /www.bbc.com/news/world-43512098. 
with International Trade Law". ${ }^{15}$ Many other smaller countries and Russia adopted trade countermeasures against the United States' neo-protectionism.

From an economic point of view, it is clear that Trump's neo-protectionist Foreign Policy will produce more losses that gains for the American Economy. Tariffs will increase the price of bringing goods to the United States and this will increase automatically the price of the imported products in the domestic market. The higher prices will cause a major supply and a lower demand for the imported goods (economic law of supply and demand) and a consequent reduction of the general number of imports to the United States. The national producers of the imports, imposed with duties, will win (in economic terms, their "producer surplus" will increase), as the tariffs protect them from the lower prices of the imports, in a free trade scenario. Nevertheless, the consumers of the imported goods, subject to tariffs, will lose (their "consumer surplus" will be reduced), as they will have to pay a higher price for the imported goods and will spend more money on less variety of products, with a presumable worst quality. Additionally, the countermeasures adopted by many other states harm the American producers, as they restrict their free access to foreign markets. Many producers, even from the "Rust Belt", have already expressed, through their representatives in the Congress, their concern about the negative consequences of Trump's Foreign Policy on their economic activities. ${ }^{16}$

In the global level, Trump's neo-protectionism will necessarily bring down the level of trade transactions and will provoke a retraction in international economy and domestic economic growth. As WTO Director, Ricardo Azevedo, preconizes: "We would see a reduction of global trade by around $17 \%$. This would cause a very significant slowdown in GDP growth, and bring major disruptions for workers, firms, and communities as they adjust to this new reality. Potentially millions of workers would need to

15 "European Commission reacts to the US restrictions on steel and aluminium affecting the EU”, European Commission, Brussels, 31 May 2018, available at: http: //trade.ec.europa.eu/ doclib/press/index.cfm?id $=1851$.

16 Davenport, Coral and Swanson, Ana, "How Trump's Policy Decisions Undermine the Industries He Pledged to Help”, The New York Times, July 4, 2018, available at: https: / /www. nytimes.com/2018/07/04/climate/trump-industry-policy-consequences.html. 
find new jobs; firms would be looking for new products and markets; and communities for new sources of growth". ${ }^{17}$

In a legal perspective, Trump's neo-protectionist tariffs violate many rules and principles of International Trade Law. The abrupt increase in the tariffs is a direct and clear violation of rules established since the entry in force of the General Agreement on Trade and Tariffs (GATT). In effect, trade practices in 1930 showed that states used the elevation of their tariff protection level as a simple negotiation strategy, aiming to put pressure on their trading partners and make them accept conditions that are more favorable for state's economic interests. In consequence, GATT's rules included a general prohibition of the sudden tariff elevation and created a system of consolidated and stabilized tariffs level, consistent with states commitments to eliminate trade barriers. ${ }^{18}$ In fact, the tariff concessions of WTO member states figure in legal documents called "Schedules of Concessions", which record members' specific commitments on tariffs and other concessions. These Schedules thus provide security and predictability of market access for goods. ${ }^{19}$ WTO rules allow states to modify and renegotiate their tariff schedules under some restrictive conditions laid down in WTO law. ${ }^{20}$ However, they can't misapply their schedules without previous

17 DG Roberto Azevêdo, "DG Azevêdo: we must turn the crisis of multilateralism into an opportunity to strengthen it", World Trade Organization, 16 November 2018, avalaible at: https: / / www.wto.org/english/news_e/spra_e/spra246_e.htm.

18 Bown, Chad et al., "Multilateral or bilateral trade deals. Lessons from history", Economics and Policy in the Age of Trump, ed. Center for Economic Policy Research, 2017, p. 154.

19 WTO Schedules of Concessions and Renegotiation of Concessions, avalaible at: https: / / ecampus.wto.org/admin/files/Course_417/Module_757/ModuleDocuments/NAMA-M4-R3-E.pdf.

20 There are different provisions dealing with the modification or withdrawal of tariff concessions and other concessions included in the Schedules. Many of these provisions allow a Member to renegotiate in order to modify or withdraw tariff and non-tariff concessions on a permanent basis subject to stipulated requirements, including compensation. The main provision in this respect is Article XXVIII of the GATT 1994, which allows a Member to enter into renegotiations in three different situations: 1) before the initiation of a three-year period; 2) in "special circumstances", subject to the authorization of other Members; or, 3) if the Member has reserved its right to do so before the initiation of the triennial period. Other relevant provisions include Article XXIV:6 of the GATT 1994, which provides for the renegotiation of tariff concessions in the context of the formation of a customs union, and Article XVIII:7 of the GATT 1994 which provides for renegotiations of concessions by developing countries for purposes of promoting the establishment of a particular industry. In addition, Article XXVII of the GATT 1994 allows a Member to withhold or withdraw a concession made during 
modification of their commitments, unless they prove there is a legal reason to do so. Additionally, if states decide to elevate their tariffs regards some WTO member states, but not regards all of them, they can incur in a violation of the most favored nation clause, under GATT Article I. ${ }^{21}$

Trump's Administration has implicitly admitted the existence of violations of WTO rules, as it has advanced one of the exceptions to the obligation to respect tariffs consolidation rules. The United States authorities have actually invoked the "national security" clause under GATT Article XXI b), ${ }^{22}$ which represents the broadest and more controversial GATT exception.

There has been a no-written consensus between member states to advocate the "national security" exception only in crisis and situations of extreme urgency that threaten the international peace and security. In practice, states have referred to article XXI b) only in war or pre-war circumstances. The United States used it against ex Czechoslovakia in 1949 during the Cold War and against Nicaragua in 1985 during the conflict with the "contras". The European Union alleged "national security" to impose

multilateral rounds of trade negotiations if the government with which the concession was negotiated does not become or has ceased to be aWTO Member (WTO Schedules of Concessions and Renegotiation of Concessions, op. cit.).

21 By virtue of article I: " 1 . With respect to customs duties and charges of any kind imposed on or in connection with importation or exportation or imposed on the international transfer of payments for imports or exports, and with respect to the method of levying such duties and charges, and with respect to all rules and formalities in connection with importation and exportation, and with respect to all matters referred to in paragraphs 2 and 4 of Article III,* any advantage, favour, privilege or immunity granted by any contracting party to any product originating in or destined for any other country shall be accorded immediately and unconditionally to the like product originating in or destined for the territories of all other contracting parties".

22 Article XXI b) reads: "Nothing in this Agreement shall be construed to require any contracting party to furnish any information the disclosure of which it considers contrary to its essential security interests; or

${ }^{\text {to }}$ prevent any contracting party from taking any action which it considers necessary for the protection of its essential security interests relating to fissionable materials or the materials from which they are derived; lating to the traffic in arms, ammunition and implements of war and to such traffic in other goods and materials as is carried on directly or indirectly for the purpose of supplying a military establishment; taken in time of war or other emergency in international relations; or to prevent any contracting party from taking any action in pursuance of its obligations under the United Nations Charter for the maintenance of international peace and security". 
a boycott to Argentine in 1982 in the middle of the Maldivian War, ${ }^{23}$ and, more recently, the Gulf States claimed the "national security" argument regards their boycott on Qatar.

Thus, it will be very difficult to conceive an application of the "national security" exception in time of peace for the United States and the world. Besides, the fact that Trump's government unilaterally advance the alleged "national security" concern without any judicial control from the WTO Dispute Settlement Body, makes the situation even more complicated. If we interpret article XXI of GATT in the light of article XX (general restrictions) we can argue that the "national security" exception should not be "applied in a manner which would constitute a means of arbitrary or unjustifiable discrimination between countries where the same conditions prevail, or a disguised restriction on international trade.” Nevertheless, the restrictions under Article XX do not apply to Article XXI ${ }^{24}$ and Trump knows it. It is too obvious for international analysts and for other states of the international community that the United States is not facing a true threat to its national security and is under no need to preserve its sovereign integrity. Trump's neo-protectionist Foreign Policy has imposed trade barriers for political and commercial reasons that have nothing to do with the "maintenance of international peace and security", "in time of war or other emergency in international relations". Under the guise of "national security", he is violating one of the most fundamental rules of International Trade Law and one of the major guarantees of legal predictability in the (past) progress of trade liberalization.

The reaction of other countries against Trump neo-protectionist's violations of International Trade Law was to introduce demands against the United States under the WTO dispute settlement mechanism. Ten demands initiated in 2017 and eighteen in 2018 25 — a record for the WTO (and

23 "Acier et aluminium : pourquoi de nouveaux droits de douane au nom de la sécurité nationale", op. cit.

24 Woods, Michael, "GATT article XXI's national security exception- the ultimate trade policy conundrum”, Woods LaFortune LPP, Mar 9, 2018, avalaible at: http://www.wl-tradelaw.com/gattarticle-xxis-national-security-exception-the-ultimate-trade-policy-conundrum /.

25 Since 2017: DS519, DS520, DS521, DS524, DS525, DS527, DS528, DS530, DS532, DS535. Since 2018: DS537, DS538, DS540, DS542, DS543, DS544, DS545, DS546, DS547, DS548, DS549, DS550, DS551, DS552, DS553, DS554, DS555, DS556, DS557, DS558, DS559, DS560, DS561, DS562, DS563, DS564, DS565, DS566 (“Current status of disputes” 
for all the mechanisms of dispute settlement in International Economic Law) - if we compare it to the three cases, pending before the Dispute Settlement Body in 2015. The United States presented many of these cases against foreign governments ${ }^{26}$ to denounce the imposition of trade barriers in response of Trump's new tariffs. However, the majority of the proceedings are against the United States and its neo-protectionist government ${ }^{27}$ and denounce serious violations of many articles of WTO's treaties. ${ }^{28}$

Thus, for example, on 15 August 2018, Turkey initiated proceedings against the United States' tariff measures on the imports of steel and aluminium, claiming their inconsistencies with articles 2.1, 2.2, 3.1, 4.1, 4.2, 5.1, 7, 8.1, 9.1, 11.1(a), 11.1(b), 12.1, 12.2 and 12.3 of the Agreement on Safeguards; articles I:1, II:1(a), II:1(b), X:3(a), XI:1, XIII:1, XIX:1(a) and XIX:2 of the GATT 1994; and Article XVI:4 of the WTO Agreement. At its meeting on 21 November 2018, the DSB established a panel and Bahrain, Brazil, Canada, China, Colombia, Egypt, the European Union, Guatemala, Hong Kong, China, Iceland, India, Indonesia, Japan, Kazakhstan, Malaysia, Mexico, New Zealand, Norway, Qatar, the Russian Federation, Saudi Arabia, Singapore, Switzerland, Chinese Taipei, Thailand, Ukraine, the United Arab Emirates and Venezuela reserved their third-party rights. The case is pending, at present. ${ }^{29}$

World Trade Organization, avalaible at: https: / / www.wto.org/english/tratop_e/dispu_e/dispu_current_status_e.htm).

26 The United States demanded Mexico, Canada, China, the EU and Turkey for the imposition of trade barriers in retaliation of the measures adopted by Trump's Government.

27 Vietnam, China, Switzerland, Russia, South Korea, Mexico, Canada and Norway initiated proceedings against Trump's administration trade measures, "Current status of disputes" World Trade Organization, avalaible at: https: //www.wto.org/english/tratop_e/dispu_e/dispu_current_status_e.htm

28 Particularly, Articles 2.1, 2. 2, 3.1, 4.1, 4.2, 5.1, 7, 8.1, 11.1(a), 11.1(b), 12.1, 12.2, 12.3 and 12.5 of the Agreement on Safeguards; Articles I:1, II:1(a), II:1(b), X:3(a), XI:1, XIX:1 and XIX:2 of the GATT 1994; Article XVI:4 of the WTO Agreement, "DS550: United States - Certain Measures on Steel and Aluminium Products", World Trade Organization, Settled or terminated (withdrawn, mutually agreed solution) on 23 May 2019, available at: https: / /www. wto.org/english/tratop_e/dispu_e/cases_e/ds550_e.htm.

29 "DS564: United States — Certain Measures on Steel and Aluminium Products", World Trade Organization, Panel composed on 25 January 2019, available at: https://www.wto.org/ english/tratop_e/dispu_e/cases_e/ds564_e.htm 
Esta revista forma parte del acervo de la Biblioteca Jurídica Virtual del Instituto de Investigaciones Jurídicas de la UNAM

In the same sense, on 8 November 2018, Switzerland requested the establishment of a panel to hear its demand against the United States concerning the protectionist measures imposed by the United States to allegedly adjust imports of steel and aluminium into the United States. Switzerland claimed that these measures were adopted in violation of Articles 2.1, 2.2, 3.1, 4.1, 4.2, 5.1, 7, 11.1(a), 12.1, 12.2, 12.3 and 12.5 of the Agreement on Safeguards; and Articles I:1, II:1(a), II:1(b), X:3(a), XI:1, XIX:1(a) and XIX:2 of the GATT 1994; and Article XVI:4 of the WTO Agreement. Bahrain, Brazil, Canada, China, Colombia, Egypt, the European Union, Guatemala, Hong Kong, China, Iceland, India, Indonesia, Japan, Kazakhstan, Malaysia, Mexico, New Zealand, Norway, Qatar, the Russian Federation, Saudi Arabia, Singapore, South Africa, Chinese Taipei, Thailand, Turkey, Ukraine, the United Arab Emirates and Venezuela reserved their third-party rights. The case is still pending, at present. ${ }^{30}$

India, China and the European Union also initiated proceedings against the United States regarding Trump's tariff measures on steel and aluminium imports into the United States and the three cases are currently pending. ${ }^{31}$

Trump's violation of free trade rules, embedded in the core of International Trade Law, alarmed many international organizations and their liberalization agenda. While some authors talk already about Beijing Woods, the two Bretton Woods institutions and the WTO issued an interesting report in 2017, in reaction of the wage of protectionism in Trump's (and other's governments) Foreign Policies. ${ }^{32}$ With no surprise, they advocated in favor of free trade and against protectionism, trying, of course, to justify their own existence and future survival. In the report, the IMF, the WB and the WTO explained to the public opinion that free trade is beneficial for domestic economies and incomes from free trade represent a gross part of countries General Domestic Product. Nevertheless, they admitted that "trade has... negatively impacted groups of workers and some communities" and insisted on the need for the states to adopt "domestic policies to address trade-related adjustments" such as search assistance, training pro-

30 "Dispute Settle,emt:The Disputes Chronological list of dsputes cases", World Trade Organization, available at: https://www.wto.org/english/tratop_e/dispu_e/dispu_status_e.htm.

31 Idem.

32 "Making Trade an Engine of Growth for All. The Case for Trade and for Policies to Facilitate Adjustment”, International Monetary Fund, April 10, 2017, avalaible at: https: / / www.imf.org/en / Publications/Policy-Papers/Issues/2017/04/08/making-trade-an-engine-of-growth-for-all. 
grams, and, in some situations, wage insurance. ${ }^{33}$ In the opinion of the profree trade international organizations, those measures should be sufficient to avoid "trade shocks" and to "lift up" again the "forgotten men and women" of the world economy. In sum, in their opinion, the real enemy of workers all around the world is not free trade, per se, but State's Governments and their bad domestic policies in addressing trade related adjustments. If we put this in the United States context, the true enemy of the "Rust Belt" workers would not be free trade, International Trade Law, Mexico or China, but Donald J. Trump.

Trump's response to "trade shocks", caused by global economic liberalization, should not be a neo-protectionist targeting on International Trade Law's norms and institutions. Market access and trade barriers elimination foster trade flows, and make grow the general size of the domestic economic "cake", if we see it like this. The problem is free trade and International Trade Law have nothing to do with the "proportional cake-cutting in pieces". The allocation of resources by free trade doesn't lead alone to redistribution and social justice. They depend entirely on states domestic policy choices and domestic legal regulations. Trump should consider revising more his Internal and less his Foreign Policy, if he wants to fight against the perverse effects of free trade on American economy and defend the interests and rights of the "forgotten ones".

The United States has given to the world many Nobel laureates in domestic and international economics. They have warned for many years their respective governments that free trade with developing countries is not the principal cause of job loss and worst life conditions of the American non- qualified workers, such as Trump voters. In his brilliant manual on "International Economics", Professor Paul Krugman (Nobel Memorial Prize in Economic Sciences, sole recipient for 2008) argues that there are no convincing evidences that free trade is, per se, responsible for job or live hood losses of American workers. The "villain" of the movie is not free trade, but technology, as it has devaluated non- qualified work. ${ }^{34}$ In the same sense, WTO's Director, Ricardo Azevedo recently argued, "the driving force behind job losses is innovation and higher productivity enabled by technology.

33 Ibidem, p. 4.

34 Krugman, Paul et al., International Economics. Theory and Practice, Pearson, 2018 
Esta revista forma parte del acervo de la Biblioteca Jurídica Virtual del Instituto de Investigaciones Jurídicas de la UNAM

$80 \%$ of jobs lost are because of these forces - not because of trade" ${ }^{35}$ As the pro-free trade international institutions have mentioned, in this regard, policies like unemployment insurance, savings, and a strong education system can help workers to respond to "free trade shocks".

However, the free trade vs. protectionism dilemma in International Economics and International Trade Law has not the same significance in Trump's Foreign Policy. Trump's Foreign Policy doesn't apply "first principles" or rules of (International) Law or Economy, it's rather a product of politics, populism and ideology. In political science, "populism is the idea that society is separated into two groups at odds with one another - "the pure people" and "the corrupt elite". ${ }^{36}$ Populist politicians like Trump would favor the defense of the "pure people's" interests in their decision-making process, even if the defense turns to be legally or economically wrong.

Multilateral cooperation has been the basis of the negotiation of legal rules and principles of International Trade Law and their embedment in international commercial treaties, since the end of the Second World War. Nevertheless, in Trump's Foreign Policy's view, those legal norms are plagued by "bad deals", that serve no more United States' national interests and pose an obstacle to "Make America Great Again".

One of Trump's principal campaign promises was the re-negotiation and/or withdraw of the United States from many international multilateral trade agreements. After winning the elections, Trump has been particularly consistent and has kept this promise. Few times after his arrival at the White House, President Trump announced United States' withdraw from the Transpacific Partnership (TPP) and initiated the re-negotiation of the North American Free Trade Agreement (NAFTA) with Mexico and Cana-

35 DG Roberto Azevêdo, "DG Azevêdo: we must turn the crisis of multilateralism into an opportunity to strengthen it", op. cit.

36 Molloy, David, "What is populism, and what does the term actually mean?", BBC News, 6 March 2018, avalaible at: https: //www.bbc.com/news/world-43301423. 
da. At the same time, Trump blocked the negotiations of the Transatlantic Partnership (TAP) with the EU and the Trade in Services Agreement (TiSA) with 24 other WTO members. Finally, Trump's Administration initiated a real "crusade" against another multilateral agreement, administered by the WTO: The Dispute Settlement Memorandum of Understanding.

The TPP was originally a free trade agreement of a "new generation", negotiated between 12 states from the Pacific Region, geographically situated in three different continents (Asia, America and Oceania). His ambitious aim was to create the bigger free trade zone of the world, represented by $40 \%$ of the global GDP and a global market of more than 800 million of people. The project of the treaty comprehended 30 Chapters, with more than 2000 pages and constituted a priority for ex-President's Barack Obama Foreign Policy in the Asia-Pacific Region. It represented not only free access for many American companies to the evolving domestic markets of the countries from this region, but if had as well a clear geo-strategic value of "containment" of the influence of China. The Obama Administration saw it as a legal tool to promote multilateral cooperation with the states of the region, in order to preserve American "guidance" and influence on their respective international agendas. It was as well an opportunity to preserve the "occidental" way of "trade liberalization by virtue of International Law" against the novelty of China's initiative "One belt, one road". ${ }^{37}$

Less concerned about the geo-political implications of the agreement, President Trump estimated that TPP was "a horrible treaty", made to convince China to be part of it. In Trump's vision, the geopolitical dimension of trade agreements doesn't matter if they cause a harm to American workers. In his Trade Policy project for 2017, Trump clearly rejected "the notion that the United States should, for putative geopolitical advantage, turn a blind eye to unfair trade practices that disadvantage American workers, farmers, ranchers, and businesses in global markets". ${ }^{38}$ After the signature of TPP withdraw decree, Trump expressed that "We want to start making our products again. We do not want to bring them in; we want to make them here. That doesn't mean we don't trade because we do trade, but we want to make our products here". He added, "It's one of the reasons I'm

37 Chaisse, Julien and Mitsuo Matshushita, "China's Belt and Road Initiative: Maping the World Trade and Specific Implications", Journal of World Trade, vol. 52, 2018, pp. 163-185.

38 USTR (2017), 2017 Trade Policy Agenda and 2016 Annual Report... cit. p. 1. 
DOI: httpa//dx_doi_org/10.22201/iij_24487872e_2020.20.14494 sitting here instead of somebody else sitting here". ${ }^{39}$ In other speeches, he qualified TPP as "a rape to our country", even if, after the entry into force of TPP $-11^{40}$ he seemed to have changed his mind and would be reconsidering to join the new agreement. ${ }^{41}$

Trump's Foreign Policy's objectives also materialized in the re-negotiation of another international multilateral trade agreement- NAFTA. In 1992, Mexico, Canada and the United States concluded NAFTA, seeking the diminution of trade (but not political) boundaries and the complementarity of the three economies in the North American Region. ${ }^{42}$ The objectives of the agreement were to "eliminate barriers to trade... promote conditions of fair competition... increase investment opportunities, provide adequate and effective protection and enforcement of intellectual property rights and create effective procedures... for the resolution of disputes". ${ }^{43}$

39 Smith, David, “Trump withdraws from Trans-Pacific Partnership amid flurry of orders”, The Guardin, 23 Jan 2017, avalaible at: https://www.theguardian.com/us-news/2017/jan/23/ donald-trump-first-orders-trans-pacific-partnership-tpp.

40 In fact, Trump's withdraw from TPP didn't cause the death of the agreement and it was actually concluded by 11 States of the Pacific Region, in Peru in the beginning of 2018.

41 Swanson, Ana, "Trump Proposes Rejoining Trans-Pacific Partnership”, The New York Times, April 12, 2018, avalaible at: https://www.nytimes.com/2018/04/12/us/politics/trump-trans-pacificpartnership.html.

42 United States is high-tec, consumption-oriented economy where services are the major sector of the economic activity. It is, thus, a very energetic- dependent economy and Mexican and Canadian economies have an energetic surplus. Additionally, regards Mexico- United States interdependency, it is worth noting that the United States is a capital abundant and capital driven economy and Mexico is a labor abundant and labor driven economy. Towards the previsions of the comparative advantage's theory, it makes it easier for them to arrange their trade relations in a more efficient way. Folsom, Ralph, NAFTA in a Nutshell, West, 2012, p. 15.

${ }^{43}$ By virtue of the agreement's Preamble: "The Government of Canada, the Government of the United Mexican States and the Government of the United States of America, resolved to: STRENGTHEN the special bonds of friendship and cooperation among their nations; CONTRIBUTE to the harmonious development and expansion of world trade and provide a catalyst to broader international cooperation; CREATE an expanded and secure market for the goods and services produced in their territories; REDUCE distortions to trade; ESTABLISH clear and mutually advantageous rules governing their trade; ENSURE a predictable commercial framework for business planning and investment; BUILD on their respective rights and obligations under the General Agreement on Tariffs and Trade and other multilateral and bilateral instruments of cooperation; ENHANCE the competitiveness of their firms in global markets; FOSTER creativity and innovation, and promote trade in goods and services that are the subject of intellectual property rights; CREATE new employment opportunities and 
DOI: httpa//dx_doi_org/10.22201/iij_24487872e_2020.20.14494

Little time after its entry into force, the treaty achieved its main objectivethe elimination of trade barriers- and launched an "All Duty Free" zone in the integrated territories of its member states. Other non- tariff barriers to trade persisted and the competition of the low prices of the imports from other (developing) countries to the North American region raised some serious questions about the benefits of NAFTA for its developed member states, especially for the United States.

Since its early presidential campaign, Donald Trump promised to his voters to re-negotiate NAFTA. After the elections, on May 18, 2017, "President Trump became the first American president to begin renegotiating a comprehensive free trade agreement like NAFTA". ${ }^{44}$ His decision to do this claimed the necessity to arrange the problems and "bleeding" that the agreement caused to many American workers, especially for American farmers and ranchers who, supposedly, had suffered its negative effects for decades. In Trump's administration point of view, "since the deal came into force in 1994, trade deficits have exploded, thousands of factories have closed, and millions of Americans have found themselves stranded, no longer able to utilize the skills for which they had been trained...". ${ }^{45}$ The re-negotiation objectives of the American government were to preserve the elimination of trade barriers to United States products, ${ }^{46}$ to reduce trade deficits with

improve working conditions and living standards in their respective territories; UNDERTAKE each of the preceding in a manner consistent with environmental protection and conservation; PRESERVE their flexibility to safeguard the public welfare; PROMOTE sustainable development; STRENGTHEN the development and enforcement of environmental laws and regulations; and PROTECT, enhance and enforce basic workers' rights."

44 Office of the United States Trade Representative, Executive Office of the President, Summary of Objectives for the NAFTA Renegotiation, July 17, 2017, avalaible at: https: / / ustr.gov/sites / default / files / files / Press / Releases / NAFTAObjectives.pdf.

45 Idem.

46 As mentioned above, one of the most important obstacles to the effectiveness of NAFTA's commitments came from non- tariff restrictions to trade, especially from the application of sanitary and phytosanitary measures. In this sense, the re-negotiation objectives of Trump administration intended to "provide for enforceable SPS obligations, including with respect to science-based measures, good regulatory practice, import checks, equivalence, regionalization, and certification and risk analysis...”. Office of the United States Trade Representative, Executive Office of the President, Summary of Objectives for the NAFTA Re-negotiation. Another problematic aspect of NAFTA application was its "rules of origin" disposals. Only goods fabricated in the North American region were able to benefit from the elimination of tariffs, but the determination of the goods origin turns particularly difficult when it comes 
Mexico and Canada and to obtain a more reciprocal and secure access to their domestic markets.

The re-negotiation of NAFTA took more than one year. In 2017, the three countries celebrated five rounds of negotiations and in 2018- two. The issues, which caused more controversies and blockages during the process, were some of the proposals of the Trump Government, especially his intention to obtain from Mexico and Canada an increase in the regional automotive content of NAFTA cars to $80 \%$ (75\%, later in the negotiations) with $50 \%$ of American content. Additionally, what caused a deterioration in the negotiation clime was Trump's initiative to eliminate the dispute settlement mechanism of NAFTA Chapter 19. ${ }^{47}$ Finally, in Trump's initial negotiation schedule figured the so-called "sunset clause" which provided for a re-negotiation and a possible expiration of the agreement's content every five years. Beside these difficulties, the parties' mutual concessions during the last stage of the negotiations, which took place during the presidential elections period in Mexico, gave results. Shortly after the election of Andrés Manuel Lopez Obrador on the top of Mexico's new government, Jesús Seade- its chief negotiator-announced that Mexico and the United States reached an agreement on the re-negotiation of NAFTA.

Trump's Foreign Policy in international trade has not been limited on withdraw and/or renegotiation of international multilateral trade agreements. Trump's vision of international trade has clashed as well with WTO and the international multilateral trade system as a whole. In many public speeches, President Trump and Robert Lighthizer- the United States'

to manufactured products, which parties may come from many different countries. The delocalization of global channels of production has replaced the label "Made in a country" with the label "Made in the world". Consequently, the United States big concern about NAFTA was always China and other countries "taking advantage" of its rules of origin regulations and importing good components in the region, that will then be sold as a final product with the beneficial trade treatment reserved for NAFTA member States. One the principal objectives of NAFTA re-negotiation was to "Update and strengthen the rules of origin, as necessary, to ensure that the benefits of NAFTA go to products genuinely made in the United States and North America" (Office of the United States Trade Representative, Executive Office of the President, Summary of Objectives for the NAFTA Re-negotiation).

47 This mechanism offers to a subject of anti-dumping proceedings in the territory of one of the contracting states to bring a claim against these proceedings before an international arbitral tribunal, who will exam and control their conformity with NAFTA rules on antidumping. 
Trade Representative- have expressed their "discontent" and "disappointment" with WTO. After the last WTO ministerial meeting in Buenos Aires, in 2017, Lighthizer mentioned that the United States is "concerned" because the WTO is losing its primary objectives and is becoming an organization, centered on disputes. In the same sense, during his official visit in Vietnam, Trump noticed that the United States, "is not treated correctly" in the WTO. According to these statements, Trump's Foreign Policy adopted measures that threaten to "kill the WTO from the inside".

As mentioned above, the "trade war" provoked by the United States' decision to increase tariffs on imports from the rest of the world is a severe violation of many articles of the multilateral trade agreements, administered by the WTO. In response to Trump's neo-protectionism, many other countries have introduced demands against the United States before the WTO Dispute Settlement Body (DSB). At present, these claims have absolutely no chance to proceed because the DSB is a true "hostage" of Trump's Foreign Policy decisions.

Trump is criticizing, in first place, the "judicial overreach" of the DSB and of its Appellate Body (AB). The AB would have exceeded its judicial function by a too extensive interpretation and application of the rules and principles of WTO law. The AB's function should be limited to settle the disputes submitted by the WTO members and to review the decisions of the ad hoc panels. Nevertheless, in its findings and recommendations, the $A B$ "cannot add to or diminish the rights and obligations provided in the cove red agreements". ${ }^{48}$ The logic of the United States is quite simple: the AB should control the panels but no one can control the $\mathrm{AB},{ }^{49}$ because "the $\mathrm{AB}$ is creating its own rules". ${ }^{50}$ Many other developing and developed countries

48 Article 19.2 of the WTO Dispute Settlement Understanding.

49 In fact, the decisions of the OA are definitive and there is no other judicial resort for their review. The reports of the OA can only be re-examed if the DSB reaches a consensus on this point. Until now, the members of the DSB have reached no consensus on this point and the OA is actually operating as a "last resort" jurisdiction.

50 A DSB, Minutes of the Meeting, April 3, 2002, WT/DSB/ M121, para. 35. This critic is due to a new trend in $\mathrm{OA}^{\prime}$ s legal reasoning. Ad hoc panels usually respect OA's final findings and there are abundant citations of its previous decisions in panel's case law. This shows the development of a stare decisis doctrine in WTO law and a progressive "jurisdictionalisation" of its dispute settlement mechanism (Payosova, Tatiana, Gary Hufbauer and Jeffrey Schott, The Dispute Settlement Crisis of the WTO: Crisis and cures, Peterson Institute of International Economics, Policy Brief, 2018, p. 3). 
DOI: httpa//dx_doi_org/10.22201/iij_24487872e_2020.20.14494 share this opinion and they presume that the $\mathrm{AB}^{\prime}$ 's "judicial overreach" is a clear violation of articles 3.2 and 19.2 of the Dispute Settlement Understanding. ${ }^{51}$ The United States also address more specific and technical critics on some relevant procedural aspects of the WTO dispute settlement mechanism. In particular, the United States' representatives have stressed that some $\mathrm{AB}$ members have decided appellation cases even after their 4 years mandate had expired, without receiving an express authorization to do so by the DSB. Trump's administration have argued as well that the Korean arbiter, Hyun Chong Kim, renounced in July, 2017 with no respect of the 90 days period of pre-advise, established in the procedural rules of the DSB and the fact that the DSB adopted his report in EU-Fatty Alcohol (DS442) case even if Hyun Chong Kim have not been replaced. Finally, the United States have contested the existence of a no written rule in favor of the re-election of the arbiters for an additional 4 years period. ${ }^{52}$

These critics are not, per se, the cause of the present crisis of the WTO dispute settlement mechanism. The direct origin of the complete blockage of the DSB is the way the Trump Administration has put them in action. In fact, given the impossibility to control the $\mathrm{AB}^{\prime}$ 's presumed "judicial overreach" by legal means, since 2017, Trump decided to block the process of nomination of its members. In December 2016, the AB still had seven arbiters. Then, in June 2017, the Mexican arbiter — Ricardo Ramírez-Hernández - ended his four years mandate and was not re-elected nor replaced, because of the United States veto in the DSB voting procedures. This reduced AB's members to six. In august 2017, the Korean Hyun Chong Kim renounced and was not replaced and the same happened with the end of the mandate of Peter Van den Bossche, in December 2017. That brought down the $\mathrm{AB}^{\prime} \mathrm{s}$ membership to four. In September 2018, ended the period of

51 Article 3.2 states: "The dispute settlement system of the WTO is a central element in providing security and predictability to the multilateral trading system. The Members recognize that it serves to preserve the rights and obligations of Members under the covered agreements, and to clarify the existing provisions of those agreements in accordance with customary rules of interpretation of public international law. Recommendations and rulings of the DSB cannot add to or diminish the rights and obligations provided in the covered agreements". By virtue of article 19.2 of the DSB, "In accordance with paragraph 2 of Article 3, in their findings and recommendations, the panel and Appellate Body cannot add to or diminish the rights and obligations provided in the covered agreements". Idem.

52 Idem. 

Shree Baboo Chekitan Servansing and Trump's persistent blockage reduced the $\mathrm{AB}$ members to three, which is the minimum required for its functioning by article 17 of the Dispute Settlement Understanding. The critical, and probably, fatidic date for the future of the AB will be December 2019, which will mark the exit of two more AB members.

If Trump's position doesn't change until then, his Foreign Policy would have been the "assassin" of one the world's more efficient mechanisms for settlement of interstate disputes. The result will be a return to the past of GATT where a party was able to block the adoption of a panel report if it was not favorable to its national trade interests. It seems that this is the true political intention of Trump's Foreign Policy- a whiter commitments to the WTO multilateral trade system, a lesser international judicial control of their fulfillment and a trade dispute resolution "à la carte" of the United States' trade interests and international agenda. As a confirmation of these estimations, one of the key objectives of Trump's International Trade Policy cynically recalls that the United States Congress has made clear that "Americans are not directly subject to WTO decisions" and that WTO adverse reports and findings are not binding or self-executing for the United States. ${ }^{53}$

Trump's attacks on the WTO dispute settlement mechanism deepen the crisis that faces nowadays this international organization. In fact, the WTO has been unable to fulfill its most fundamental statutory objectives. Because of the consensual nature of its institutional design, the geographical extension of its membership and the substantial changes in the economic power balance between its developing and developed member states, at present, all the decision-making procedures at WTO are blocked. The consensus as mechanism of decision-making in a "member-driven" organization has been able to preserve state sovereignty, but, at the same time, it has affected the organization's ability to administer efficiently the international trade agree-

53 In Trump's Policy Objectives we can read that: "it is important to recall also that Congress had made clear that Americans are not directly subject to WTO decisions. The Uruguay Round Agreements Act states that, if a WTO dispute settlement report "is adverse to the United States, [the U.S. Trade Representative shall] consult with the appropriate congressional committees concerning whether to implement the report's recommendation and, if so, the manner of such implementation and the period of time needed for such implementation," confirming that these WTO reports are not binding or self-executing” (USTR, 2017 Trade Policy Agenda and 2016 Annual Report, Washington, Office of the United States Trade Representative). 
ments. The failure of Doha Round to reach comprehensive trade deals has shown, additionally, that WTO is no more the major negotiation forum of International Trade Law. The discrepancies between developed and developing states on number of issues, such as agriculture and subsidies, trade in services, competition, environment and intellectual property have shifted the "single undertaking" rule, as a technique for multilateral trade negotiation and have put WTO's trade multilateralism in an impasse. WTO law and WTO itself need urgent reforms if the organization wants to survive to Trump's crusade against it and be an active institutional player in International Trade Law. However, state practice and Trump's Foreign Policy makeWTO's future uncertain and brings the path of the legal regulation of international trade far away from multilateralism and back to regional (subregional, inter-regional and intra-regional) deals and agreements.

Trump's Foreign Policy towards WTO and multilateralism in International Trade Law is consistent with Trump's vision of commercial (national or international) deals. It's clear that the United States government has a real problem with multilateralism and trade cooperation among states. In the economic and trade policies' field Trump is, in fact, an avowed adept of bilateralism, mercantilism and nationalism. As stated in his Official Trade Policy key objectives for 2017: "As a general matter, we believe that these goals can be best accomplished by focusing on bilateral negotiations rather than multilateral negotiations - and by renegotiating and revising trade agreements when our goals are not being met". ${ }^{54}$

Trump's bilateralism in international trade policy inspires itself from the mercantilist theory of international trade, developed in Europe, in the 16th Century. Mercantilist authors assume a strong governmental intervention in foreign trade volume and nature and use taxes on trade as a tool to manipulate the trade balance in favor of their own domestic economy. In mercantilists view, a country should try to maximize exports, minimize imports ${ }^{55}$ and accumulate precious metals that would permit it to reach a positive trade balance with constant trade surpluses in its international relations. Mercantilism's two primary objectives are: accumulate gold to reinforce the monarch's power and promote trade and industrial develop-

54 Ibidem, p. 1.

55 Trump's trade policy is stuck in the ' $80 \mathrm{~s}$ - the 1680s, avalaible at: https: / /www.washingtonpost.com/opinions/trumps-trade-policy-is-stuck-in-the-80s-the-1680s/2018. 
ment in the domestic economy. A mercantilist trade policy is about increasing exports of manufactures and imports of primary inputs, ${ }^{56}$ prohibition of imports of manufactured goods and exports of primary inputs, and concession of monopolies to private investors. In the mercantilist world, the military power determinate the economic wealth of nations. War is also an instrument of foreign trade for mercantilists, as it serves the preservation of trade monopolies and economic dominance. Their ultimate objective, so far, is to win wars as a key to assure economic and trade success. ${ }^{57}$

The idea of maintaining trade surpluses on every cost explains why a mercantilist, as Trump, will have no consideration for multilateral trade techniques and negotiations and would prefer trade bilateralism. Trump's mercantilist world of international trade is a world where "no one trusts anyone". It is a zero-sum view of the world. Nothing is a "win-win" game, everything is perceived as "I win- you lose", and everyone is suspicious of everyone else, ${ }^{58}$ as the need to maintain trade surplus pushes trade partners to "take advantage" from one another. Bilateralism is the best way to negotiate in a world where mutual (and comparative) advantages don't exist and where "everyone cheats on everyone". In this sense, Trump's bilateralism and mercantilism in international trade sees every other country as "enemy" and "loser", and the United States as the potential winner- the one who gets trade surplus in bilateral relations. Even the supposed friends of the United States, or its "closest allies", are blamed to cheat in international trade and have to be treated suspiciously. In some of his speeches, Trump mentioned in this sense: "Frankly, our friends did more damage to us than our enemies" and, "Because we didn't deal with our enemies, we dealt with our friends, and we dealt incompetently". ${ }^{59}$ His intention to reach "better deals" for the United States is almost a vision of "barter deals" with increased reciprocity of the commitments.

Bilateral deals are closest to Trump's mercantilist "zero-sum" vision of trade, as they permit to one of the parties in the negotiations to impose

56 In this sense, many authors have mentioned that even if Trump is inspired by mercantilism, he would be missing one of mercantilists main arguments, when applying higher tariffs on aluminum and steel imports.

57 Comín Comín, Francisco, Historia económica mundial. De los orígenes a la actualidad, Alianza, 2013

58 Trump's trade policy is stuck in the ' 80 s — the 1680 s, op. cit.

59 Idem. 
its economic and commercial interests to the other. Trump exports his businessman's domestic negotiation tactics of "bluff", "bluster" and "bullying" to the international level and uses them aggressively toward the United States' trading partners. His bilateralism seeks to take advantage of the major size of the United States' economy and trade power to "convince" other smaller and less powerful countries to adhere to international trade deals. For a small country (or even for a big country, like Mexico) economic dependency on exports to the United States market can be a very strong reason to adhere to Trump's proposals during bilateral negotiations. In bilateralism, the bigger and stronger the trade partner is, the more chances he must win better legal and political conditions for himself. Ultimately, trade power through bilateralism can easily impose its own interests to the smaller and the weaker.

Bilateral approach to international trade represents a past period in the history of International Trade Law and it is precisely in response to its negative effects that state members of the international community, with the United States leadership, decided to build the international liberal trade order after the Second World War.

In fact, all the $19^{\text {th }}$ century legal regulation of international trade was bilateral ${ }^{60}$ with relative success. However, what moved International Trade Law from bilateralism to multilateralism after the Second World War was not the $19^{\text {th }}$ Century experience, but rather the use of bilateralism in the interwar period. In fact, during the decade of 1930, many countries, including the United States developed preferential bilateralism. In this period, discriminatory trade blocs and protectionist bilateral trade agreements contributed to one of the most severe global trade contractions in the world economic history. The bourse crack of "the black thursday" and the devastation "debts" of the First World War (hyperinflation, huge foreign debts, and high cost of the reconstruction, political and social instability) precipitated the "Great Depression" in the United States and its sparrow all over the world. The GDP in the United Stated descended by 10\% between 1929 and 1933 and the unemployment rates reached 36\%. In response, the United States govern-

60 Trade growth in $19^{\text {th }}$ century was the result of a web of bilateral commercial agreements between European states. For example, the Anglo-French accord of 1783 involved the elimination of prohibitions and a modest reduction of duties on bilateral trade. Irwin, Douglas, Multilateral and bilateral trade policies in the world trading system: an historical perspective 

ment adopted the famous Smoot-Hawley Tariff Act in 1930, which increased the duties and tariffs on imports to the United States of more than 20, 000 products. Many countries, like Canada, Spain, Italy and Switzerland adopted direct retaliations, imposing tariff, and non- tariff trade barriers to United States exports. Other states, particularly, the United Kingdom, retailed indirectly and reduced trade barriers with other partners on a discriminatory basis. ${ }^{61}$ These protectionists and preferential trade policies conducted to the creation of "economic areas", like the "sterling trade zone", the "dollar bloc", the "gold bloc" and the "Nazi bloc". These blocs' main objectives were to "empoorish the neighbor" and their direct result was a disintegration of international finance and trade. ${ }^{62}$ The bilateral trade deals were de facto barter deals, based on quantitative protectionism that reinforced state control over immigration and state dirigisme over the economy. The failure of this politics originated Roosevelt's "New Deal" decision to insert a most favored nation clause in the United States' international trade agreements.

The disaster of bilateralism in international trade policies, like the one chosen by Trump's Administration, strengthened the resolve of international lawmakers after the Second World War to construct a rule based multilateral trading system that would prevent any return to depredatory bilateralism in international commercial relations. It was in everyone's mind in this period that Hitler was himself a true bilateralist. In fact, the Nazi Germany oriented its Foreign Trade Policy toward a rigid system of bilateral trade and clearing agreements. This system turned successful for German domestic economic growth because of the exploitation of Hitler's trading partners. Germany was the largest trading partner of many smaller European states and issued on this basis a theory on monopolistic power in international trade. The ultimate objective was to build an informal German Economic Empire. ${ }^{63}$

In this regard, by attacking multilateralism in International Trade Law, Trump's Bilateralist Foreign Trade Policy is testing some of the hardest lessons of the United States' and world's legal and economic history. The

61 Bown, Chad et al., op. cit.

62 Comín Comín, Francisco, op. cit.

63 Ritschl, A., "Nazi economic imperialism and the explotation of the small: evidence from Germany's secret foreign exchange balances”, 1938-1940, Economic History Review, 2001, vol. LIV, p. 324. 
Esta revista forma parte del acervo de la Biblioteca Jurídica Virtual del Instituto de Investigaciones Jurídicas de la UNAM

buildings of multilateralism in International Trade Law and in international relations, in general, aim, above all, to preserve cooperation between states and maintain "peace through law". The bilateral and mercantilist Foreign Policy of President Trump is possibly bringing the United States and the world in the interwar context of "trade wars", which preceded the military Second World War. It is a context divided in economic and geo-political blocs, controlled by trade powers with imperialistic ambitions to extend their spheres of influence, in a clear hostility ones vis-à-vis the others. ${ }^{64}$ The devise "America First" of Trump's Internal and Foreign Policy is provoking, more than ever, an "Anti-America" sentiment in its trading and political partners.

\section{CONCLUSION}

Trump's Foreign Policy threat on International Trade Law's fundamental norms and institutions is creating a risk for the international liberal order, as a whole. The size of the risk should not be overestimated and could end with the new Presidential campaigns in the United States, if Trump was to lose his re-election. Nevertheless, the risk seems more serious as Trump's neo-protectionism and bilateralism are signs of more systemic problems of the international liberal order, that might be independent from Trump's political life and future.

Both neo-protectionism and bilateralism manifest a broader crisis in international multilateral cooperation. Symptoms can be identified everywhere. The European Union's model of the world's most successful regional integration has faced the danger of des-integration after the decision of the United Kingdom to leave it. Some African states announced they are planning to withdraw from the Rome Statute - the ambitious multilateral treaty that created the International Criminal Court - because of its "racist" and "neo-colonial" judicial processes. Burundi and Gambia actually retired from the Court. Bolivia, Ecuador and Venezuela denounced the Washington Convention on Settlement of Investment Disputes- another comprehensive

64 Ikenberry, John, "The Plot Against American Foreign Policy, Can the liberal order survive?", Foreign Affairs, June 2017, p. 5. 
multilateral treaty, arguing it had established a "colonial" system of "slavery" of States towards multinational companies. ${ }^{65}$ South Africa, Indonesia ${ }^{66}$ and India ${ }^{67}$ are re-negotiating their bilateral investment treaties. Uzbekistan decided to exit (again) the Collective Security Treaty Organization Permanent member states of the UN Security Council are blocking, more than usually, its decision- making process by their veto power.

The crisis causes are multiple and complex. The new geo-political power balance in foreign affairs and the decline of the United States hegemony have shaped new alliances and unilateral entrenchments. These new divisions are the result of the failure of international multilateral institutions to achieve their respective goals and missions. The UN has been unable to "maintain international peace and security" and to prevent the return of war in the relations between states. The WTO has failed to complete a single round of trade negotiations and isn't able to administer the trade agreements, reached during the Marrakech Round. The World Bank had not eradicated global poverty and the International Monetary Fund has not prevented the financial crisis and their consequences on domestic and world's economies.

Additionally, there is a perception that international multilateral institutions have been too binding on States' Foreign Policy and international agenda. Trump's arguments on WTO DSB's “judicial overreach” summarize a more systematic critic of the constraining nature of "hard" International (Trade) Law as an instrument to control power at the international level. International (trade) norms and institutions would have "tied too much the hands" of states. Sovereignty delegations by countries to multilateral international (trade) institutions was to serve the interests of all members, towards reciprocity, where "no one lose and no one wins, all the time". However, nowadays, many people would agree with Trump that multilater-

65 Correa, Rafael, "Correa suscribe decreto que da por terminado convenio con el CIADI", El Tiempo, 03 de julio de 2009, avalaible at: http://www.eltiempo.com.ec/noticias/economia / 1 /211881/correa-suscribe-decreto-que-da-por-terminado-convenio-con-el-ciadi.

66 "After South Africa, Indonesia takes a brave decision to terminate its Bilateral Investment Treaty with the Netherlands", SOMO, March 24, 2014, avalaible at: https: / /www.somo. $\mathrm{nl} /$ after-south-africa-indonesia-takes-a-brave-decision-to-terminate-its-bilateral-investment-treatywith-the-netherlands/.

67 Smith Freehills LLP, Herbert, "India seeks to re-negotiate Bilateral Investment Treaties with over 47 countries", LEXOLOGY, India, July 7, 2016, avalaible at: https: / / www.lexology. com/library/detail.aspx? $g=e 9408$ e6c-fa1b-47cf-9206-8517de5ac5fc. 
Esta revista forma parte del acervo de la Biblioteca Jurídica Virtual del Instituto de Investigaciones Jurídicas de la UNAM

DOI: http://dx.doi.org/10.22201/iij.24487872e.2020.20.14494 alism in International (Trade) Law has created only "winners" and "losers", even if it's time for a re-adjustment period of "taking sovereignty back".

The problem with taking back sovereignty and attacking multilateralism in International Law, generally, and in International Trade Law, particularly, is that the attacks will re-introduce national power in commercial relations between states. In addition, national power's visions of international trade are, by definition, imperialistic and discretionary. They turn to be particularly conflicting with the International Rule of Law and international peace. In sum, they have the potential to create not only "trade wars", but also war, perse.

At present, we are assisting "the greatest presidential onslaught on international law and international institutions in American history". ${ }^{68}$ In this sense, Trump's Foreign Policy effects on International Trade Law and other branches of International Law will ultimately depend on the stability and resistance of multilateralism and cooperation mechanisms of the international legal and political system. Will Trump's Foreign Policy mortally wind the norms and institutions of International Trade Law or will they survive and be reformed and modernized? Will the present "trade war" put in true danger the international peace and security? Perhaps yes, but only future can tell.

\section{BIBLIOGRAPHY}

Acier et aluminium: pourquoi de nouveaux droits de douane au nom de la sécurité nationale, France 24, Publié le: 09/03/2018 - 17:47 Modifié le : 09/03/2018 - 20:14, avalaible at: https://www.france24.com/ fr/20180309-acier-aluminium-douane-protectionnisme-securite-nationaletrump-omc-regle.

AZEVÊDO, Roberto, "DG Azevêdo: we must turn the crisis of multilateralism into an opportunity to strengthen it", World Trade Organization, 16 November 2018, avalaible at: https://www.wto.org/english/news_e/ spra_e/spra246_e.htm.

68 Bosco, David, "We've been Here Before: the Durability of Multilateralism”, Journal of International Affairs, 2017, avalaible at: https://jia.sipa.columbia.edu/we\%E2\%80\%99ve-beenhere-durability-multilateralism. 
BALDWIN, Richard, Multilateralizing Regionalism. Challenges for the Global Trading System, ed. World Trade Organization- Cambridge, 2009.

Bhagwati, Jagdish and PanagariYa, Arvind, "The Theory of Preferential Trade Agreements: Historical Evolution and Current Trends", The American Economic Review, 1996, vol. 86.

Bosco, David, "We've been Here Before: the Durability of Multilateralism", Journal of International Affairs, 2017, avalaible at: https://jia.sipa. columbia.edu/we\%E2\%80\%99ve-been-here-durability-multilateralism.

Bown, Chad et al., "Multilateral or bilateral trade deals. Lessons from history", Economics and Policy in the Age of Trump, ed. Center for Economic Policy Research, 2017.

Chaisse, Julien and Matshushita, Mitsuo, "China's Belt and Road Initiative: Maping the World Trade and Specific Implications", Journal of World Trade, 2018, vol. 52.

Comín Comín, Francisco, Historia económica mundial. De los orígenes a la actualidad, Madrid, Alianza, 2013.

CONESA, Elsa, "Trump et les oubliés de la Rust Belt", Les Echos, 17/05/17 à 18h27, avalaible at: https://www.lesechos.fr/17/05/2017/lesechos. fr/0212101931369_trump-et-les-oublies-de-la-rust-belt.htm.

CorREA, Rafael, "Correa suscribe decreto que da por terminado convenio con el CIADI", El Tiempo, 3 de julio de 2009, avalaible at: http: / / www. eltiempo.com.ec/noticias/economia / 1 / 211881 / correa-suscribe-decreto-queda-por-terminado-convenio-con-el-ciadi.

Davenport, Coral and Swanson, Ana, "How Trump's Policy Decisions Undermine the Industries He Pledged to Help", The New York Times, July 4, 2018, avalaible at: https://www.nytimes.com/2018/07/04/climate/ trump-industry-policy-consequences. html.

European Commission, "European Commission reacts to the US restrictions on steel and aluminium affecting the EU”, Brussels, 31 May 2018, avalaible in: http: / / trade.ec.europa.eu/doclib/press/index.cfm?id=1851.

FOLSOM, Ralph, NAFTA in a Nutshell, West, 2012.

IKenBerry, John, "The Plot Against American Foreign Policy, Can the liberal order survive?”, Foreign Affairs, 2017, may-june.

International Monetary Fund, "Making Trade an Engine of Growth for All. The Case for Trade and for Policies to Facilitate Adjustment", April 10, 2017, avalaible at: https://www.imf.org/en/Publications/Policy-Papers/Issues /2017/04/08/making-trade-an-engine-of-growth-for-all. 
Esta revista forma parte del acervo de la Biblioteca Jurídica Virtual del Instituto de Investigaciones Jurídicas de la UNAM

Krugman, Paul et al., International Economics. Theory and Practice, Pearson, 2018.

MOLlOY, David, What is populism, and what does the term actually mean? BBC News,6 March 2018, avalaible at: https://www.bbc.com/news/ world-43301423.

Office of the United States Trade Representative, Executive Office of the President, Summary of Objectives for the NAFTA Re-negotiation, July 17, 2017, avalaible at: https://ustr.gov/sites/default/files/files/Press/Releases / NAFTAObjectives. $p d f$.

Organización Mundial del Comercio, Acuerdos comerciales regionales y arreglos comerciales preferenciales, 2019, avalaible at: https: //www.wto.org/spanish / tratop_s/region_s/rta_pta_s.htm.

Payosova, Tatiana et. al., The Dispute Settlement Crisis of the WTO: Crisis and cures, Peterson Institute of International Economics, Policy Brief, 2018.

Petrova GeOrgieva, Virdzhiniya, "La "judicialización": una nueva característica del orden jurídico internacional”, Anuario Mexicano de Derecho Internacional, vol. XV, enero de 2015.

RITSCHL, "A. Nazi economic imperialism and the explotation of the small: evidence from Germany's secret foreign exchange balances, 1938-1940”, Economic History Review, vol. LIV, 2001.

Siroen, Jean-Marc, "L'OMC: une institution en crise”, Alternatives Économiques, num. 240, 2008.

SMITH FREEHILLS, Herbert Llp, "India seeks to re-negotiate Bilateral Investment Treaties with over 47 countries”, Lexology, India, July 7 2016, avalaible at: https://www.lexology.com/library/detail.aspx? $g=e 9408$ e6c-fal b47cf-9206-8517de5ac5fc.

SMITH, David, "Trump withdraws from Trans-Pacific Partnership amid flurry of orders", The Guardian, 23 Jan 2017, avalaible at: https: / / www. theguardian.com/us-news / 2017 /jan/23/donald-trump-first-orders-transpacific-partnership-tpp.

Somo, "After South Africa, Indonesia takes a brave decision to terminate its Bilateral Investment Treaty with the Netherlands", March 24, 2014, avalaible at: https: / / www.somo.nl/after-south-africa-indonesia-takes-a-bravedecision-to-terminate-its-bilateral-investment-treaty-with-the-netherlands / .

SwAnson, Ana, "Trump Proposes Rejoining Trans-Pacific Partnership", The New York Times, April 12, 2018, avalaible at: https://www.nytimes. com/2018/04/12 /us/politics/trump-trans-pacific-partnership.html. 
Esta revista forma parte del acervo de la Biblioteca Jurídica Virtual del Instituto de Investigaciones Jurídicas de la UNAM

TheWashington Post, "Trump's trade policy is stuck in the '80s - the 1680s", avalaible at: https: / /www.washingtonpost.com/opinions/trumps-trade-policyis-stuck-in-the-80s--the-1680s/2018/05/31/f8e2f7c2-6510-11e8-a69cb944de66d9e7_story.html.

Office of the United States Trade Representative, Trade Policy Agenda and 2016 Annual Report, Washington, DC.

“Trade wars, Trump tariffs and protectionism explained”, BBC News, 10 May 2019, avalaible at: https://www.bbc.com/news/world-43512098.

Office of the United States Trade Representative, USTR, Trade Policy Agenda and 2016 Annual Report, Washington, DC, 2017.

World Trade Organization, Vietnam, China, Switzerland, Russia, South Korea, Mexico, Canada and Norway initiated proceedings against Trump's administration trade measures, "Current status of disputes", avalaible at: https: / / www.wto.org/english/tratop_e/dispu_e/dispu_current_status_e.htm. Woods, Michael, "GATT Article XXI's National Security Exception- the Ultimate Trade Policy Conundrum”, Woods LaFortune LPP, Mar 9, 2018, avalaible at: http://www.wl-tradelaw.com/gatt-article-xxis-national-securityexception-the-ultimate-trade-policy-conundrum/.

World Trade Organization, "Current status of disputes", avalaible at: https: / / www.wto.org/english/tratop_e/dispu_e/dispu_current_status_e.htm.

World Trade Organization, Schedules of Concessions and Renegotiation of Concessions, avalaible at: https://ecampus.wto.org/admin/files/ Course_417/Module_757/ModuleDocuments/NAMA-M4-R3-E.pdf.

World Trade Organization, "Dispute Settlement: Understanding on rules and procedures governing the settlement of disputes", avalaible at: $h t$ tps://www.wto.org/english/tratop_e/dispu_e/dsu_e.htm.

World Trade Organization, "Dispute Settle, emt: The Disputes Chronological list of disputes cases", avalaible at: https: / /www.wto.org/english/ tratop_e/dispu_e/dispu_status_e.htm.

World Trade Organization, "DS550: United States - Certain Measures on Steel and Aluminium Products", Settled or terminated (withdrawn, mutually agreed solution) on 23 May 2019, avalaible at: https://www.wto. org/english/tratop_e/dispu_e/cases_e/ds550_e.htm.

World Trade Organization, "DS564: United States - Certain Measures on Steel and Aluminium Products", Panel composed on 25 January 2019, avalaible at: https: / / www.wto.org/english/tratop_e/dispu_e/cases_e/ ds564_e.htm. 